\title{
Global Obligations to Ensure the Right to Health
}

\author{
Strengthening Global Health Governance to Realise Human Rights in \\ Global Health
}

\author{
Benjamin Mason Meier,* Judith Bueno de Mesquita, ${ }^{* *}$ \\ and Caitlin R. Williams****
}

The COVID-19 pandemic has reaffirmed the need for the world to come together to realise human rights in global health, with global governance institutions in place to coordinate a global rights-based health response to a shared threat. However, the COVID-19 response has revealed nationalist obstacles to global solidarity. The United Nations (UN) system is confronting increasing disengagement from global governance, as nationalist impulses have driven isolationist responses. States have failed to heed UN calls for global solidarity, neglecting their extraterritorial obligations of assistance and cooperation under international human rights law, with catastrophic consequences for the right to health. Without strong foundations of extraterritorial human rights obligations in global health governance, the World Health Organisation (WHO) has faced constraints in realising the right to health in the pandemic response. However, new opportunities are arising in the pandemic to strengthen human rights in global health. This changing global health governance landscape in the COVID-19 response will require renewed attention to extraterritorial human rights obligations, including through advancing global obligations in global governance to promote the right to health throughout the world.

Centrally protected under international human rights law, extraterritorial human rights obligations frame (i) State actions and omissions that affect human rights beyond their territory and (ii) global obligations to take action separately and through international cooperation to realise human rights universally. These obligations accord with, and legally underpin, calls for global solidarity

\footnotetext{
* $\quad$ Professor of Global Health Policy at UNC-Chapel Hill.

** Senior Lecturer, and Co-Deputy Director of the Human Rights Centre, in the School of Law, University of Essex.

*** Doctoral Candidate at the UNC-Gillings School of Global Public Health.

$* * * *$ The authors are grateful for the research assistance of Hanna Huffstetler, Meredith Dockery, Anahita Gupta, Christopher Burch, and Savannah Faircloth, whose inspiring work gives us hope for the future of human rights in global health governance.
} 
and provide a framework for the universal realisation of the right to health through global health governance. However, global obligations have long been neglected in the evolution of international human rights law and have been given only vague recognition in global health law. In applying global obligations in global health governance, these extraterritorial obligations can provide a legal foundation for global health, global equity and global solidarity.

This article examines the changing global health governance landscape in the pandemic response, analysing opportunities and obstacles for implementing global obligations. Outlining how international organisations have advanced human rights to bring nations together in responding to global health threats, Part 2 chronicles the evolution of human rights in global health governance to address infectious disease threats. However, these international institutions have faced increasing pressures from nationalist governments, with Part 3 looking to the ways in which isolationism has presented obstacles to public health, human rights, and global solidarity in the pandemic response. These structural limitations in the pandemic response require a focus on extraterritorial obligations under the right to health. Drawing on international human rights law and global health law, Part 4 analyses the sources and nature of these extraterritorial obligations, examining their evolving development under international law but limited implementation in the COVID-19 response. With extraterritorial obligations encompassing global obligations through global governance, Part 5 analyses the imperative for institutional reforms to support global solidarity in the pandemic response, examining new paths for realising global human rights obligations through strengthened wно leadership and coordination across the larger system of international organisations, re-centring human rights in global health governance. This article concludes that strengthening global obligations through the global governance landscape will be crucial to realising human rights in global health, facilitating solidarity beyond the pandemic response to realise the right to health for all.

\section{2 \\ International Organisations Have Sought to Bring the World Together to Realise Human Rights in Global Health Governance}

Since the birth of the UN, international organisations have remained critical to the advancement of human rights in global health. Although wHo long languished in efforts to advance human rights in global health governance, the UN has moved in recent decades to mainstream human rights across the full range of organisations, funding agencies, and international bureaucracies that 
work across sectors to influence global health. ${ }^{1}$ These international organisations, including WHO, are increasingly seen as a part of the UN's human rights system, ${ }^{2}$ with their governance responsibilities framed by international human rights law ${ }^{3}$ and serving as a necessary bridge between principle and practice to support human rights implementation. ${ }^{4}$ Bearing human rights obligations as representatives of the international community, these international organisations have assumed responsibilities to implement human rights in the global response to infectious disease.

\subsection{Foundations of Human Rights in Global Health Governance}

The modern global health and human rights architecture arose from the ashes of international crisis. Out of the ruins of World War II, the UN was formed, bringing nations together to address collective threats through international action. In requiring States 'to take joint and separate action in cooperation with the Organisation [UN]', 5 the UN would seek to 'make recommendations for the purpose of promoting respect for, and observance of, human rights and fundamental freedoms for all.' ${ }^{6}$ Signed on June 26,1945 , the UN Charter elevated human rights as a central pillar of the post-war international system and called for the establishment of a new international health organisation - to provide an institutional foundation for international cooperation to advance public health. ${ }^{7}$

The 1946 wно Constitution, establishing wHO as an international organisation and UN specialised agency, served as the first international treaty to conceptualise a human right to health, declaring that 'the enjoyment of the highest attainable standard of health is one of the fundamental rights of every

1 Benjamin Mason Meier and Lawrence O. Gostin, 'Responding to the Public Health Harms of a Globalizing World through Human Rights in Global Governance' in Human Rights in Global Health: Rights-Based Governance for a Globalizing World (OUP 2018).

2 Philip Alston, The United Nations and Human Rights: A Critical Appraisal (1992); Dinah L. Shelton, 'Introduction' in The United Nations System for Protecting Human Rights (Routledge 2014).

3 Brigit Toebes, Lisa Forman and Giulio Bartolini, “Toward Human Rights-Consistent Responses to Health Emergencies: What Is the Overlap between Core Right to Health Obligations and Core International Health Regulation Capacities?', (2020) 22 Health and Human Rights, 99.

4 Paul Hunt, 'Configuring the UN Human Rights System in the "Era of Implementation": Mainland and Archipelago', (2017) 39 Human Rights Quarterly, 489.

5 United Nations, Charter of the United Nations (1946), art. 56.

6 Ibid., art. 62(2).

7 Marcos Cueto, Theodore M. Brown, and Elizabeth Fee, The World Health Organization: A History (CUP 2019). 
human being.8 ${ }^{8}$ Under wHO's Constitution, Member States would engage a pressing post-war imperative to facilitate international health cooperation through wHO governance. ${ }^{9}$ With wHO coming into existence as the UN finalised the 1948 Universal Declaration of Human Rights (UDHR), there was great promise that these institutions would complement each other to realise health and human rights. ${ }^{10}$

Yet despite this constitutional mandate, wHO was slow to embrace the right to health in global health governance, as other international organisations forged ahead of wHo in advancing human rights in their health-related policies, programmes, and practices. ${ }^{11} \mathrm{~A}$ wide range of international organisations would take steps to integrate human rights in their institutional mandates to advance public health - from the International Labour Organisation (ILO), which promoted human rights in conventions on occupational safety and health, to the United Nations Children's Fund (UNICEF), which reformed its mission to address child health under the UN Convention on the Rights of the Child. ${ }^{2}$ This expansion of human rights across the institutional landscape reflected a shift away from the traditional State-centric conception of human rights obligations under international law, approaching human rights as a direct responsibility of international organisations. ${ }^{13}$ As organisations beyond WHO embraced human rights as a foundation for their institutional priorities, this shift brought renewed attention to human rights mandates across the full range of institutions within the UN system.

The end of the Cold War brought about a new consensus on human rights in global governance. Memorialised at the 1993 World Conference on Human Rights, the resulting Vienna Declaration and Programme of Action called for

8 World Health Organization, Preamble of the Constitution of the World Health Organization (1946).

$9 \quad$ Ibid., art. 2.

10 Benjamin Mason Meier, 'Global Health Governance and the Contentious Politics of Human Rights: Mainstreaming the Right to Health for Public Health Advancement', (2010) 46 Stanford Journal of International Law, 1-50.

11 Benjamin Mason Meier and Florian Kastler, 'Development of Human Rights Through WHO' in Benjamin Mason Meier and Lawrence O. Gostin (eds.), Human Rights in Global Health: Rights-Based Governance for a Globalizing World (oup 2018).

12 Benjamin Mason Meier and Lawrence O. Gostin, 'Advancing Human Rights through Global Health Governance' in Foundations of Global Health and Human Rights (ouP 2020).

13 Margot E. Salomon, Global Responsibility for Human Rights: World Poverty and the Development of International Law (oup 2007); Elena Pribytkova, 'What Global Human Rights Obligations Do We Have?', (2020) 2o Chicago Journal of International Law, 339. 
greater 'international cooperation and solidarity' for human rights, recommended increased coordination on human rights across the UN system, and called on all UN bodies 'to cooperate in order to strengthen, rationalise and streamline their [human rights] activities.'14 In the years that followed, the UN Secretary General sought to reinforce efforts to centre human rights in global governance, calling for a 'cross-cutting' approach to human rights across all UN activities and programmes. ${ }^{15}$ This push to 'mainstream' human rights throughout the UN's activities - grounded in the UN Charter's mandate to achieve international cooperation in promoting respect for human rights - prompted many UN programmes, specialised agencies, and funds to explicitly adopt a rights-based approach to their work. ${ }^{16}$ Building on these initiatives across the $\mathrm{UN}$, WHO increasingly integrated human rights in its policies and programmes, with human rights mainstreaming efforts extending to global governance over infectious disease. ${ }^{17}$

\subsection{Human Rights in Infectious Disease Governance}

WHO's constitutional framework established a human rights mandate for WHO authority to direct international action for infectious disease control, empowering WHO to negotiate international agreements to prevent, detect, and respond to public health emergencies. However, when the World Health Assembly first adopted the International Health Regulations (IHR), the primary legal instrument governing infectious disease, it failed to enshrine human rights obligations in framing global responsibilities to respond to infectious diseases that pose an international threat. It was not until the early $198 \mathrm{os}$, with the rise of the HIV/AIDS pandemic, that WHO began to address human rights in its infectious disease efforts, acknowledging an inextricable linkage between health and human rights. ${ }^{18}$ When the IHR were revised in 2005, WHO

14 United Nations General Assembly, Vienna Declaration and Programme of Action (1993), Part II, Paragraph 1.

15 United Nations Secretary General, Renewing the United Nations: A Programme for Reform (1987), UN Doc A/51/95o.

16 Joel E. Oestreich, Power and Principle: Human Rights Programming in International Organizations (GUP 2007).

17 Benjamin Mason Meier, Senait Fisseha, and Judith Bueno de Mesquita, 'The Development and Implementation of Human Rights Law in WHO Governance' in Scarlett McArdle and Stephanie Switzer (eds.), Elgar Companion to the Law and Practice of the World Health Organisation (Elgar, forthcoming).

18 Benjamin Mason Meier and William Onzivu, 'The evolution of human rights in World Health Organization policy and the future of human rights through global health governance', (2014) 128 Public Health, 179. 
would ensure that the revisions incorporated human rights as a cross-cutting principle in infectious disease governance, ${ }^{19}$ with IH R (2005) recognising that the 'implementation of these Regulations shall be with full respect for the dignity, human rights and fundamental freedoms of persons.' ${ }^{20}$ These efforts provided a legal foundation to align global health law with human rights law in infectious disease prevention and control, with overlapping norms aiding treaty interpretation across legal regimes. ${ }^{21}$

Complementing wHO leadership in infectious disease governance, the larger UN system has looked to human rights obligations to frame global health initiatives to respond to infectious disease. UN action to address global health has increased dramatically over the past three decades, with inter alia the United Nations Population Fund (UNFPA) implementing sexual and reproductive health and rights to prevent sexually transmitted infections, ${ }^{22}$ the Joint United Nations Programme on HIV/AIDS (UNAIDS) emphasizing equity, nondiscrimination, and participation in HIV prevention and treatment, ${ }^{23}$ and UNICEF looking to the rights of the child to frame immunisation programmes. ${ }^{24}$ In creating new international institutions to implement human rights in global health, the establishment of the Global Fund on AIDs, Tuberculosis and Malaria has leveraged human rights to address the ongoing pandemics of $\mathrm{HIV}$, tuberculosis, and malaria, employing global health funding to facilitate accountability for rights-based approaches to national public health policy. ${ }^{25}$

19 Lisa Forman, Sharifah Sekalala, and Benjamin Mason Meier, 'The World Health Organization, International Health Regulations \& Human Rights Law', (forthcoming) International Organizations Law Review.

$20 \quad$ World Health Organization, International Health Regulations (2005), art 3.

21 Brigit Toebes et al. (n 4), 99.

22 Emilie Filmer-Wilson and Luis Mora, "The United Nations Population Fund: An Evolving Human Rights Mission and Approach to Sexual and Reproductive Health and Reproductive Rights' in Benjamin Mason Meier and Lawrence O. Gostin (eds) Human Rights in Global Health: Rights-Based Governance for a Globalizing World (OUP 2018).

23 Helena Nygren-Krug, 'The Joint United Nations Programme on HIV/AIDS: With Communities for Human Rights' in Benjamin Mason Meier and Lawrence O. Gostin (eds.), Human Rights in Global Health: Rights-Based Governance for a Globalizing World (oup 2018).

24 Benjamin Mason Meier, Mitra Motlagh, and Kumanan Rasanathan, "The United Nations Children's Fund: Implementing Human Rights for Child Health' in Benjamin Mason Meier and Lawrence O. Gostin (eds.), Human Rights in Global Health: Rights-Based Governance for a Globalizing World (oup 2018).

25 Ralf Jürgens, Joanne Csete, Hyeyoung Lim, Susan Timerlake, and Matthew Smith, 'The Global Fund to Fight AIDS, Tuberculosis and Malaria: Funding Basic Services and Meeting the Challenge of Rights-Based Programs' in Benjamin Mason Meier and Lawrence O. 
The UN General Assembly has repeatedly incorporated human rights in resolutions on infectious disease control, bringing the world together under human rights in the HIV/AIDS pandemic, ${ }^{26}$ and later addressing human rights in access to medicines, ${ }^{27}$ malaria eradication, ${ }^{28}$ antimicrobial resistance, ${ }^{29}$ and the ongoing CoviD-19 pandemic. ${ }^{30}$

At the onset of the COVID-19 response, the UN looked to human rights in responding to a shared global threat. UN High Commissioner for Human Rights Michelle Bachelet called on States and international organisations to take a human rights-based approach to the pandemic in an early April 2020 briefing to the Human Rights Council. ${ }^{31}$ In the UN's policy brief later that month, UN Secretary-General António Guterres highlighted the centrality of human rights in the pandemic response across organisations. ${ }^{32}$ Where initial WHO efforts were highly technical in their focus on disease containment, wHO Director-General Tedros Adhanom Ghebreyesus came to include explicit calls to protect human rights in the pandemic response, invoking the right to health as a foundation of all of WHO's efforts. ${ }^{33}$ From an early focus on maintaining essential healthcare facilities and protecting medical personnel under the right to health, wHO would release rights-based guidance on reducing gender-based violence and addressing mental health considerations during the pandemic,

Gostin (eds.), Human Rights in Global Health: Rights-Based Governance for a Globalizing World (oup 2018).

26 United Nations General Assembly, Prevention and control of acquired immunodeficiency syndrome (AIDS) (1987), UN Doc. A/42/PV.48.

27 United Nations General Assembly, Access to medication in the context of pandemics such as HIV/AIDs, tuberculosis and malaria (2003), UN Doc. A/58/PV.77.

28 United Nations General Assembly, 2001-2010: Decade to Roll Back Malaria in Developing Countries, Particularly in Africa (2009), UN Doc. A/64/PV.6o; United Nations General Assembly, Consolidating gains and accelerating efforts to control and eliminate malaria in developing countries, particularly in Africa, by 2015 (2011), UN Doc. A/65/PV.86.

29 United Nations General Assembly, Political Declaration of the high-level meeting of the General Assembly on antimicrobial resistance (2016), UN Doc. A/71/PV.24.

30 United Nations General Assembly, Special session of the General Assembly in response to the coronavirus disease (COvID-19) pandemic (2020), UN Doc. A/75/L.8; United Nations General Assembly, Women and girls and the response to the coronavirus disease (Covid19) (2020), UN Doc. A/75/471; United Nations General Assembly. Human rights in the administration of justice (2020), UN Doc. A/75/478/Add.2, para. 89 .

31 Michelle Bachelet, "COVID-19 is "a colossal test of leadership" requiring coordinated action, High Commissioner tells Human Rights Council' (2020).

32 António Guterres and UN, We Are All In This Together: Human Rights and COVID-19 Response and Recovery (2020).

33 WHо, wHо Director-General's opening remarks at the media briefing on Covid-19 (2020). 
reinforcing that every individual has the right to 'enjoyment of the highest attainable standard of health.' ${ }^{34}$ WHO came to see human rights and the right to health as an integral part of the public health response, emphasising the stigma and discrimination faced by affected populations, engaging human rights obligations in framing the health system response, and releasing guidance to support Member States in developing rights-based responses to public health emergencies. ${ }^{35}$ Yet as the UN system has sought to bring the world together through human rights in responding to the global threat of covid19, nationalism has continued to undermine human rights in global health governance, as international organisations have faced continuing obstacles in realising public health, human rights, and global solidarity.

\section{Nationalist Governments Neglect Public Health, Undermine Human Rights, and Subvert Global Solidarity}

Once relegated to the fringe of the contemporary global community, nationalism has risen to increasing prominence in international affairs, threatening UN leadership in global health governance. Spurred by the failures of globalisation to deliver on promises of widespread global prosperity, nationalist leaders have rallied supporters around an illusory vision of returning the nation to a simpler, imagined past. This populist appeal has come to fruition through the imposition of isolationist policies and the rejection of cosmopolitan ideals, including human rights and global governance. ${ }^{36}$ Retracting from shared global commitments, nationalist governments have sought to recast international relations through a realist lens, claiming that international agreements allow other nations to prosper at the expense of their own citizens. While such nationalist challenges to global governance were rising prior to the current pandemic response, the emergence of CoviD-19 has exacerbated this threat, challenging human rights under international law as a basis for public health.

34 WHo, Mental health and psychosocial considerations during the covid-19 outbreak (2020); WHO, COVID-19 and violence against women (2020); Committee on Economic, Social and Cultural Rights, General Comment No. 14: The Right to the Highest Attainable Standard of Health (Art.12) (2000).

35 wHO, Addressing Human Rights as Key to the COVID-19 Response (2020).

36 Caitlin R. Williams, Jocelyn Getgen Kestenbaum, and Benjamin Mason Meier, 'Populist Nationalism Threatens Health and Human Rights in the COVID-19 Response', (2020) 110 American Journal of Public Health, 1766. 


\subsection{Nationalist Leaders Defy Human Rights and Undermine Global Institutions}

After a period of relative cooperation among States under the immediate post-Cold War international order, nationalist sentiment is again resurgent in international affairs. Across the globe, leaders have turned from cosmopolitan ideals of global governance to advance nationalist positions, exemplified by nation "first" rhetoric on the global stage. Paradoxically, these nationalist impulses have manifested both as isolationist retreats from the global commitments and as aggressive territorial claims beyond national boundaries. With leaders withdrawing from international diplomacy to focus on domestic concerns, ${ }^{37}$ this weakening of global governance has allowed States to expand their material and security interests unilaterally, engaging in both territorial annexation and bilateral initiatives while side-lining multilateral governance through the UN system. ${ }^{38}$ Where global governance is largely reliant on mutual cooperation in the absence of strict enforcement, each nation that chooses to bypass UN institutions further undermines the effectiveness and authority of global governance. ${ }^{39}$

With the rise of nationalism, attacks on human rights have come to be seen as both intrinsic to nationalist identity and instrumental to nationalist ends. In defining the bounded membership of the nation, casting all "others" as threats to national identity, ${ }^{40}$ nationalist leaders have undercut the human rights ideal that all people are equal in dignity and rights. Such denigration of human rights, attacking rights as an international imposition that thwarts national sovereignty, has permitted nationalist leaders to demonise human rights proponents as 'globalist' elites seeking to impose purportedly 'foreign' values on the nation. ${ }^{41}$ These attacks on human rights serve both to undermine the authority of international human rights institutions and to silence those who would highlight rights violations perpetrated by nationalist regimes. To

37 Christopher R Yukins and Micheal Bowsher, 'Brexit and the Trump Election: Finding a Way Forward for Transnational Procurement', (2016) 11 European Procurement \& Public Private Partnership Law Review, 258.

38 Hall Gardner, 'The Russian annexation of Crimea: regional and global ramifications', (2016) 17 European Politics and Society; Michael Clark, 'The Belt and Road Initiative: China's New Grand Strategy?', (2017) 24 Asia Policy, 71.

39 Inken von Borzyskowski and Felicity Vabulas, 'Hello, goodbye: When do states withdraw from international organizations?', (2019) The Review of International Organizations, 335.

40 Pontus Odmalm and Eve Hepburn, The European Mainstream and the Populist Radical Right (Routledge 2017).

41 Ewen Speed and Russell Mannion, 'The rise of post-truth populism in pluralist liberal democracies: challenges for health policy', (2017) 6 International Journal of Health Policy and Management, 249 . 
the extent that human rights have been mainstreamed into global governance institutions, backlash against human rights has threatened the entire post-war system of global health governance. ${ }^{42}$

Populist nationalism has thus presented rising challenges to efforts to promote health-related human rights through global governance institutions. Framing human rights as an unnecessary contrivance in times of health crisis, Philippine President Duterte has dismissed UN censures and investigations of extrajudicial killings occurring in his 'war on drugs'.43 Threatening support for sexual and reproductive health and rights, U.S. President Trump pushed to remove funding from UNFPA, denying $\$ 75$ million that the UN had budgeted to ensure safe abortions, reduce gender-based violence, and prevent maternal death. ${ }^{44}$ Indian Prime Minister Modi joined in policies to destabilise UN systems, defying the UN Security Council by sending troops to Kashmir, curtailing access to health care among minority populations, and blocking health care providers from accessing needed information and supplies. ${ }^{45}$ These violative actions undercut the mainstreaming of human rights in global health.

Without pressure from human rights law, nationalist leaders have also sought to spurn cosmopolitan ideals of international cooperation through global governance. Increased isolationism, driven by nationalist goals and a zero-sum view of international affairs, has led States to retrench toward domestic concerns, neglecting international obligations. Numerous high-income States have reduced their contributions to both multilateral institutions and bilateral assistance, reflecting a diminishing commitment to assist other nations. ${ }^{46}$ Such refusals to meet assessed contributions to international organisations and agreed targets for international assistance have important implications for the abilities of low- and middle-income countries to maintain their health

42 Lawrence O. Gostin, Andres Constantin, and Benjamin Mason Meier, 'Global health and human rights in the age of populism', in Benjamin Mason Meier and Lawrence O. Gostin (eds.), Foundations of Global Health and Human Rights (OUP 2020).

43 Mark R. Thompson, 'Duterte's Violent Populism: Mass Murder, Political Legitimacy and the "Death of Development" in the Philippines', (2021) Journal of Contemporary Asia.

44 Stacy Banwell, 'Gender, North-South relations: reviewing the Global Gag Rule and the defunding of UNFPA under President Trump', (2020) 41 Third World Quarterly.

45 Nida S. Zubairi and Omar J. Baqal, 'Kashmir: Public health and human rights crises', (2021) 7 Health and Human Rights Journal.

46 Lawrence O. Gostin and Robert Archer, 'The duty of state to assist other states in need: Ethics, human rights, and international law', (2017) 34 Journal of Law, Medicine, and Ethics, 526; Philip Loft and Philip Brian, 'Reducing the UK's Aid Spend in 2021' (House of Commons Library 2021). 
systems, ensure the health and wellbeing of their populations, and meet their domestic human rights obligations. ${ }^{47}$

These nationalist attacks undermined human rights and global governance in the years leading up to the COVID-19 pandemic. State withdrawals from UN institutions limited international authority to coordinate a global public health response, ${ }^{48}$ with heightened political polarisation constraining institutional efforts to advance human rights as a foundation of global health governance. ${ }^{49}$ With the global health governance system beset by challenges and struggling to respond to a rapidly changing environment in international affairs, nationalist governments were primed to choose isolation and non-cooperation in the face of a global health crisis.

\subsection{Isolationist Policy Stymies the Pandemic Response}

Although international cooperation is vital in responding to infectious disease in a globalising world, the pandemic threat of CoviD-19 emerged amidst rising nationalism, prompting a rapid devolution toward isolationist responses - to the detriment of public health, global governance, and human rights. National governments raced to shut borders, halt international travel, and bar the trade of supplies necessary to combat the pandemic..$^{50}$ Bidding wars on personal protective equipment, medications, and vaccines followed, further jeopardising public health across countries. ${ }^{51}$ After the initial outbreak of covid-19 in China, reporting delays hampered wHO's coordination of a global response. ${ }^{52}$ The populist governments of Brazil, the United States, and the United Kingdom were among those declining to follow WHO's scientific guidance, exacerbating

47 Rachel Hammonds and Gorik J. Ooms, 'National foreign assistance programs: Advancing health-related human rights through shared obligations for global health', in Benjamin Mason Meier and Lawrence O. Gostin (eds.) Human Rights in Global Health: Rights-Based Governance for a Globalizing World (OUP 2018).

48 Inken Borzyskowski and Felicity Vabulas, 'Hello, goodbye: When do states withdraw from international organizations?', (2019) The Review of International Organizations, 335.

49 Lawrence O. Gostin, Andres Constantin, and Benjamin Mason Meier (n 43).

50 Shamilla Devi, 'Travel Restrictions Hampering COVID-19 Response', (2020) 395 The Lancet, 1331 .

$5^{1}$ Simon J. Evenett, 'Sicken thy neighbor: The initial trade policy response to COVID-19', (2020) 43 The World Economy.

52 Lawrence O. Gostin, Roojin Habibi, and Benjamin Mason Meier, 'Has Global Health Law Risen to Meet the COVID-19 Challenge? Revisiting the International Health Regulations to Prepare for Future Threats', (2020) 48 Journal of Law, Medicine \& Ethics, 376. 
infection risks globally. ${ }^{53}$ Building from previous attacks on global governance institutions, Member States undermined wHo's leadership and refused to meet their financial obligations - with the United States, wHO's largest donor, seeking to withdraw entirely. ${ }^{54}$ Isolationist governments also weakened global governance through IHR violations, ranging from State refusals to share timely and accurate information with WHO to State failures to act on WHO's warnings and recommendations. ${ }^{55}$

These efforts to subvert wHO authority have been mirrored by attempts to stymie UN action. Reliant on international cooperation, the UN system has faced challenges in rising above nationalist interests to coordinate a global response. ${ }^{56}$ Despite multiple UN General Assembly resolutions calling for mutual solidarity and global cooperation as a human rights obligation, ${ }^{57}$ early responses were largely fragmented, as wealthy States snapped up needed supplies and medications, leaving low- and middle-income countries ill-equipped to protect the health of their populations. ${ }^{58}$ Conflicts between the United States and China about the origins of the pandemic gridlocked the UN Security Council during crucial periods in the pandemic response, further complicating international coordination..$^{59}$ Seeking to further consolidate domestic power, many isolationist leaders denigrated efforts to coordinate a global response, using rhetoric and policy to suggest that their States would be better off alone. These isolationist impulses abandoned international cooperation when collective action was needed most, neglecting human rights in global health and grinding the world to a halt.

53 Gavin Yamey and Clare Wenham, 'The U.S. and U.K. Were the Two Best Prepared Nations to Tackle a Pandemic - What Went Wrong?', (2020) Time.

54 Lawrence O. Gostin, Harold Hongju Koh, Michelle Williams, et. al., 'United States Withdrawal from the World Health Organization is Unlawful and Threatens Health and Security Everywhere', (2020) 396 The Lancet, 293.

55 Lawrence O. Gostin, Roojin Habibi, and Benjamin Mason Meier (n 53) 376.

56 Ilona Kickbusch, Gabriel M Leung, and Zuliqar A Bhutta, 'Covid-19: how a virus is turning the world upside down', (2020) 369 в MJ, 1336.

57 United Nations General Assembly, Resolution 74/270 Global solidarity to fight the coronavirus disease 2019 (COVID-19) (2020); UN General Assembly, Resolution 74/274 International cooperation to ensure global access to medicines, vaccines and medical equipment to face COVID-19 (2020).

58 Devon E. McMahon, Gregory A. Peters, Louise C. Ivers, and Esther E. Freeman, 'Global resource shortages during COVID-19: Bad news for low-income countries', (2020) PLOS Neglected Tropical Diseases.

59 Lawrence O. Gostin, Suerie Moon, and Benjamin Mason Meier, 'Re-Imagining Global Governance for Health in the Age of COVID-19', (2020) 110 American Journal of Public Health, 1615 . 
In violating human rights in the pandemic response, many domestic policies exploited infection control imperatives as a rationale for imposing rights restrictions that had nothing to do with safeguarding public health. ${ }^{60}$ While international human rights law allows for certain rights restrictions when facing a national emergency, such limitations and derogations must be time-bound, proportionate, prescribed by national law, implemented in a non-discriminatory fashion, and 'strictly required by the exigencies of the situation' - conditions not necessarily met by all domestic responses. ${ }^{61}$ Although UN agencies sought to push back against these rights-restricting responses, decrying State violations of international law in the pandemic response, these UN efforts were rebuffed by governments set on pursuing nationalist ends. Beyond domestic violations, human rights were also neglected on the global stage. Aligned with the UN Secretary General's call for global solidarity, ${ }^{62}$ WHO looked to the right to health to provide a human rights foundation for international cooperation in the COVID-19 response. ${ }^{63}$ However, despite repeated WHO pleas for global solidarity in the COVID-19 response, many high-income States in the Global North failed to provide sufficient international assistance and cooperation, threatening the health and human rights of all, particularly populations in low-income States in the Global South. ${ }^{64}$

This neglect of global solidarity has only grown with the development of COVID-19 vaccines. High-income States moved quickly to stockpile vaccine supplies to the exclusion of the Global South. Fears about the implications of 'vaccine nationalism' were soon realised in a rapidly evolving context of 'vaccine apartheid', 65 as many nations in Africa, Asia, and South America remained

6o Caitlin R. Williams, Jocelyn Getgen Kestenbaum, and Benjamin Mason Meier, 'Populist Nationalism Threatens Health and Human Rights in the COVID-19 Response', (2020) 110 American Journal of Public Health, 1766.

61 Judith Bueno de Mesquita, Benjamin Mason Meier, and Anuj Kapilashrami, 'Human Rights Impacts of the COVID-19 Response (Background Paper 11)', (2021) Independent Panel on Pandemic Preparedness and Response.

62 United Nations Secretary General, 'Opening Remarks on 'COVID-19 Pandemic Calls for Coordinated Action, Solidarity, and Hope', (2020) United Nations University News.

63 Dainius Pūras, Judith Bueno de Mesquita, Luisa Cabal, Allan Maleche, and Benjamin Mason Meier, 'The right to health must guide responses to COVID-19', (2020) 395 The Lancet, 1888.

64 Judith Bueno de Mesquita and Benjamin Mason Meier, 'Moving Towards Global Solidarity for Global Health through Multilateral Governance in the Covid-19 Response', in Carla Ferstman and Andrew Fagan, (eds) Covid-19, Law and Human Rights: Essex Dialogues (2000) 31 .

65 WHO, Director-General's opening remarks at Paris Peace Forum Spring Meeting 17 May 2021 (2021). 
completely unable to access vaccine supplies while others in North America and Europe had supplies that far exceeded the needs of their populations. ${ }^{66}$ Where certain vaccine candidates were initially developed under the promise of global distribution, vaccine patents have created bottlenecks to universal access, with vaccine diplomacy unable to resolve tensions between human rights law and intellectual property regimes. ${ }^{67}$ Measures to relieve such tensions through the World Trade Organization (WTO), through either a temporary waiver or compulsory licensing of vaccine patents under the Agreement on Trade-Related Aspects of Intellectual Property Rights (TRIPs Agreement), have thus far made minimal headway in international negotiations. ${ }^{68}$ Access to vaccine supplies has remained severely limited in the Global South even as wealthy States in the Global North have pursued "booster" vaccines. ${ }^{69}$ wHO has exhorted States to support global governance as a moral imperative to realise global solidarity, yet wealthy States in the Global North have been slow to support the Covid19 Vaccine Global Access (COVAX) initiative, a global governance institution to expand vaccine distribution. These States have largely denied that they are bound by human rights to provide international assistance through vaccine access, framing their contributions as acts of charitable largesse rather than as legal obligations. Although extraterritorial obligations have been established under international human rights law, years of neglect and resistance in international relations have left international organisations unable to enforce these obligations through global health governance.

\section{4 \\ Implementing Extraterritorial Human Rights Obligations through Global Health Governance}

In promoting cooperation between States, the UN Charter obligates States to cooperate with the UN in realising human rights throughout the world. Recognising that 'all human beings are born free and equal in dignity and rights',

66 Agnes Binagwaho, Kedest Mathewos, and Sheila Davis, 'Time for the ethical management of COVID-19 vaccines', (2021) 9 The Lancet Global Health, 1169 .

67 Peter J. Hotez and K.M. Venkat Narayan, 'Restoring Vaccine Diplomacy', (2021) 325 JAMA, 2337.

68 Fides A. del Castillo, 'Temporary waiver of intellectual property on Covid-19 vaccines: toward the creation of a better, post-pandemic society', (2021) 43 Journal of Public Health, 559; Salla Sariola, 'Intellectual property rights need to be subverted to ensure global vaccine access', (2021) BMJ Global Health.

69 Michael Leigh, 'Vaccine diplomacy: soft power lessons from China and Russia?', (2021) Bruegel Blog. 
the UDHR acknowledged a global imperative for international cooperation, declaring that 'everyone is entitled to a social and international order in which the rights and freedoms set forth in this Declaration can be fully realised. ${ }^{70}$ This cosmopolitan framing of human rights through global governance has come to encompass extraterritorial obligations of States, international organisations, and other actors. In progressively realising the right to health, these extraterritorial obligations require that States provide assistance to, and cooperation with, WHO and other rights-based global health institutions. Yet despite the evolution of these health-related extraterritorial human rights obligations under international law, global health governance institutions have faced limitations in implementing these rights in the COviD-19 response.

\subsection{Conceptualising Extraterritorial Obligations}

Extraterritorial obligations bind States to respect, protect, and fulfil human rights beyond their borders. ${ }^{71}$ Committing to individual and joint action to realise human rights, these extraterritorial obligations complement States' domestic obligations to those within their territories, recognising that the enjoyment of human rights in a globalising world is often determined by actors beyond the State, including other States, international organisations, and private actors. Although the development of international human rights law following World War II predominantly focused on the State's domestic responsibilities - with an individual rights-holder left to make claims against a national duty-bearer - the rise of the Global South forced a re-examination of this exclusively domestic conception of human rights, viewing traditional human rights frameworks as an extension of colonial domination and seeking an enhanced emphasis on extraterritorial obligations as a basis for equitable development and global solidarity. ${ }^{72}$ Positing legal obligations that extend beyond national borders - conceptualising international assistance and cooperation not as a voluntary, charitable gesture, but rather as a binding form of reparative and distributive justice to rectify past and ongoing structural harms - States in the Global South pressed for enhanced recognition

70 United Nations General Assembly, Universal Declaration of Human Rights (1948), arts. 1 and 28 .

71 Extraterritorial Obligations Consortium, The Maastricht Principles on Extraterritorial Obligations of States in the Area of Economic, Social and Cultural Rights (2011).

72 Robert E. Mazur, 'Realization or deprivation of the right to development under globalization? Debt, structural adjustment, and poverty reduction programs', (2004) 6o GeoJournal, 64 . 
of extraterritorial obligations under international law. ${ }^{73}$ In a divided world characterised by increasing socio-economic inequality, extraterritorial obligations could provide an international legal foundation for realising human rights equitably and underpinning solidarity globally.

Extraterritorial obligations embrace negative and positive duties to realise the health of individuals and communities throughout the world. ${ }^{74}$ The human right to the highest attainable standard of health, codified seminally under the 1966 International Covenant on Economic, Social, and Cultural Rights (ICESCR), obligates States to progressively realise health care and underlying determinants of health, including water, sanitation, nutrition and adequate shelter and steps to prevent, treat and control infectious, endemic, and occupational diseases. ${ }^{75}$ These health services, goods, and facilities should be

- available in adequate numbers;

- accessible - physically, economically, as well as through accessible health information;

- acceptable to all and respectful of medical ethics; and

- of good quality. ${ }^{76}$

Given that the realisation of the right to health entails a focus on underlying determinants of health, this individual right encompasses collective dimensions in a globalizing world, ${ }^{77}$ implicating collecting rights to public health through extraterritorial obligations.

Extraterritorial human rights obligations provide a foundation for global health partnerships to realise the right to health, creating a normative and legally binding framework to structure global health governance on the basis of solidarity, equality, and justice. ${ }^{78}$ These obligations imply that states must

73 Stephen Marks, 'Integrating a Human Rights-Based Approach to Development and the Right to Development into Global Governance for Health' in Benjamin Mason Meier and Lawrence O. Gostin (eds.), Human Rights in Global Health: Rights-Based Governance for a Globalizing World (oup 2018) 344.

74 Judith Bueno de Mesquita, Paul Hunt and Rajat Khosla, Rajat, 'The human rights responsibility of international assistance and cooperation in health', in Mark Gibney and Sigrun Skogly (eds.), Universal Human Rights and Extraterritorial Obligations (University of Pennsylvania Press 2012) 104.

75 International Covenant on Economic, Social and Cultural Rights (1966), G.A. Res. 2200A (XXI), art. 12.

76 Committee on Economic, Social and Cultural Rights, General Comment No. 14: The Right to the Highest Attainable Standard of Health (Art. 12) (2000).

77 Benjamin Mason Meier, 'Employing Health Rights for Global Justice: The Promise of Public Health in Response to the Insalubrious Ramifications of Globalization', (2006) 39 Cornell International Law Journal, 711.

78 Benjamin Mason Meier and Ashley M. Fox, 'International obligations through collective rights: Moving from foreign health assistance to global health governance', (2010) 12 Health \& Human Rights, 65. 
be able to enter global health negotiations not merely with a plea for charity, but on the basis of a right to international assistance and cooperation. ${ }^{79}$ Since the ability of many States to realise the right to health at the domestic level is constrained by the actions and institutional arrangements of the international community, the realisation of extraterritorial obligations requires a restructuring of foreign assistance and international institutions. Yet, despite their codification under international human rights law, these obligations have remained marginalised in global health practice, with high-income States, international organisations, and non-State actors pursuing international cooperation through political commitments, moral duties, and charitable benevolence while undermining attempts to develop and implement extraterritorial obligations under international law.

\subsection{Evolving Human Rights Obligations}

Extraterritorial obligations of States have evolved under international human rights law to advance the human right to health. Extending human rights beyond the relationship between a State and the individuals within its territory, the ICESCR required States 'to take steps individually and through international assistance and cooperation, especially economic and technical, to the maximum of its available resources .... ${ }^{80}$ Following from early interpretive efforts to expound the legally-binding nature of extraterritorial obligations, ${ }^{81}$ the UN Committee on Economic, Social and Cultural Rights (CESCR), with a UN mandate to interpret ICESCR obligations, has begun to clarify extraterritorial obligations in relation to the right to health. Through General Comment 14, the CESCR reiterated in 2000 that obligations to respect, protect, and fulfil the right to health include international assistance and cooperation, and that it is particularly incumbent on States parties and other actors in a position to assist, to provide "international assistance and cooperation, especially economic and technical" which enable developing countries to fulfil their core and other

79 Lawrence O. Gostin and Robert Archer, 'The duty of states to assist other states in need: Ethics, human rights, and international law', (2007) 35 Journal of Law, Medicine \& Ethics, $5^{26 .}$

8o International Covenant on Economic, Social and Cultural Rights (1966), G.A. Res. 2200A (XXI), art. 12.2. For a discussion of other treaties, see Malcolm Langford, Fons Coomans, and Felipe Gómez Isa, 'Extraterritorial Duties in International Law' in Malcolm Langford (eds), Global Justice, State Duties: The Extraterritorial Scope of Economic, Social, and Cultural Rights in International Law (CUP 2013) 51.

81 Committee on Economic, Social and Cultural Rights, General Comment 3, the Nature of States Parties' Obligations (Fifth Session, 199o), UN Doc. E/1991/23, Annex III at 86 (1991), para. 2. 
obligations .... ${ }^{82}$ These obligations embrace commitments to engage in conduct and to achieve results in global health governance, including in areas of essential medicines, immunisation and the prevention, treatment, and control of epidemic and endemic diseases. ${ }^{83}$ While highlighting that particular duties of assistance fall on high-income States, all States bear assistance obligations according to capacity, including in relation to non-financial assistance and in relation to international cooperation. ${ }^{84}$ These extraterritorial obligations - to be respected, protected, and fulfilled where other States lack capacity to realise rights through domestic means - are implemented alongside domestic obligations, requiring States to realise human rights individually and collectively by way of rights-based cooperation in global governance structures. ${ }^{85}$

These extraterritorial obligations thereby frame human rights realisation through institutional duties in global health governance. The CESCR has specified that extraterritorial obligations require the right to health to be given attention in international agreements, finding that States should ensure that their international agreements do not adversely impact on the right to health and that States should 'consider the development of further legal instruments' to this end. ${ }^{86}$ Applied to global governance institutions, the CESCR has clarified that obligations under the ICESCR apply in the context of State membership in international organisations, with States bearing a positive obligation to do all they can to ensure that international organisations pay attention to human rights, including the right to health. ${ }^{87}$ These international organisations also bear independent obligations to realise the right to health, complementing the extraterritorial obligations of their Member States. ${ }^{88}$ The UN Special Rapporteur on the right to health has sought to interpret States' human rights obligations, including extraterritorial obligations, in the context of

82 Committee on Economic, Social and Cultural Rights, General Comment No. 14: The Right to the Highest Attainable Standard of Health (Art.12) (2000), para. 45 .

83 Ibid., paras. $43^{-44}$.

84 Wouter Vandenhole and Wolfgang Benedek, 'Extraterritorial Human Rights Obligations and the North South Divide' in Malcolm Langford (eds.), Global Justice, State Duties: The Extraterritorial Scope of Economic, Social, and Cultural Rights in International Law (CUP 2013).

85 Pribytkova (n 14) 431.

86 Committee on Economic, Social and Cultural Rights, General Comment No. 14: The Right to the Highest Attainable Standard of Health (Art.12) (2000), para. 39.

87 See, for example Committee on Economic, Social and Cultural Rights, Concluding Observations: Germany (Twenty-sixth Session, 2001) UN Doc. E/C.12/1/Add.68, para. 3; Committee on Economic, Social and Cultural Rights (n 86) para. 39. Committee on Economic, Social and Cultural Rights (n 86) para. 39. 
their membership in organisations such as the World Bank and International Monetary Fund. ${ }^{89}$ In the context of the COVID-19 pandemic, the CESCR and the UN Special Rapporteur on the right to health have repeatedly recognised that global health governance is central to realising the right to health, clarifying that State obligations under the right to health require cooperation with WHO, as well as support in other international organisations to ensure universal access to vaccines and other determinants of health..$^{90}$

Despite this legal grounding in international human rights law, State compliance with extraterritorial obligations remains limited. High-income States in the Global North have resisted efforts to implement international assistance and cooperation as binding international legal obligations. ${ }^{91}$ Concerned that legal obligations would require specific resource transfers, high-income States have instead pursued global solidarity as a moral responsibility, ${ }^{92}$ looking to non-binding political commitments through global health partnerships, from the Declaration of Alma-Ata (1978) to the Sustainable Development Goals (2015). ${ }^{93}$ This political opposition has stymied the interpretive development, implementation of, and accountability for extraterritorial obligations under international law. Facilitating this neglect of extraterritorial human rights obligations, international human rights mechanisms have continued to focus their oversight activities on domestic obligations to the detriment of extraterritorial obligations. The enduring State-centric and domestic approach to international human rights law has precluded accountability for the extraterritorial

89 Paul Hunt, Report of the UN Special Rapporteur on the right of everyone to the attainment of the highest attainable standard of physical and mental health (2008), UN Doc. A/63/263, paras. $60-61$.

90 Committee on Economic, Social and Cultural Rights, Statement on the coronavirus disease (Covid-19) Pandemic and Economic, Social and Cultural Rights (2020) UN Doc. E/C.12/2020/1, para. 23 .

91 Margot Salomon, Global Responsibility for Human Rights: World Poverty and the development of International Law (OUP 2007) 99.

92 Commission on Human Rights, Report of the Open-Ended Working Group to Consider Options Regarding the Elaboration of an Optional Protocol to the International Covenant on Economic, Social and Cultural Rights on Its Second Session, U.N. Doc. E/CN.4/2005/52, February 10, 2005, para. 76; Michael H. Posner, 'The Four Freedoms Turn 70: Embracing an Integrated Approach to Human Rights' (2011) 105 Proceedings of the Annual Meeting (American Society of International Law), 27.

93 Declaration of Alma-Ata International Conference on Primary Health Care, Alma-Ata, USSR, 6-12 September 1978; United Nations General Assembly, Transforming Our World: the 2030 Agenda for Sustainable Development (2015) A/RES/7O/1. 
obligations of States and international organisations in global health. ${ }^{94}$ States in the Global North have continued to look at international assistance merely as a matter of charity in global health governance - a moral responsibility rather than a legal obligation. Where international organisations have provided technical guidance and support to countries to implement human rights, this has focused on domestic reforms rather than international cooperation. Without support from the human rights system, global health governance has established only a vague and limited set of standards in developing global partnerships to meet the shared global health threat of COviD-19.

\subsection{Extraterritorial Obligations in Global Health Governance}

Reflecting this neglect of extraterritorial obligations underinternational human rights law, States have developed only broad declaratory language on extraterritorial obligations in the World Health Assembly, under the IHR and across global health policies, leaving States without the clear guidance to implement these obligations in the COVID-19 response. The IHR (2005) require 'collaboration and assistance' in meeting global health obligations; however, without consensus on these shared responsibilities, the exact nature and scope of these extraterritorial obligations - as well and their relationship with extraterritorial human rights obligations - remain ambiguous, with the IHR providing only that States shall collaborate 'to the extent possible'. ${ }^{95}$ Where IH R obligations of States to 'undertake to collaborate with each other' are divorced from human rights law, the precise level and kind of cooperation required of each State has been left to State interpretation, minimising IH R commitments to collaborate with each other and with wHO. ${ }^{96}$ The IHR outline various ways that States shall 'undertake to' collaborate, but without setting specific targets, this intentional legal ambiguity has denied the obligation clear meaning and acted as a barrier to compliance with extraterritorial obligations. ${ }^{97}$ In the absence of formal oversight procedures or institutional accountability mechanisms, State compliance with these extraterritorial obligations under the IHR have been neglected in global health governance.

94 Elena Pribytkova, 'Are There Global Obligations to Assist in the Realization of Socio-Economic Rights?', 54 N.Y.U. Journal of International Law \& Politics (forthcoming 2021).

95 World Health Organization, International Health Regulations (2005), art. 44.

96 Margherita M. Cinà et al., 'The Stellenbosch Consensus on the International Legal Obligation to Collaborate and Assist in Addressing Pandemics: Clarifying Article 44 of the International Health Regulations', (2020) International Organizations Law Review. 
Given these limitations in clarifying and overseeing extraterritorial obligations for global health, the global community has largely neglected these obligations in the COVID-19 response. WHO has highlighted that a human rightsbased response to the pandemic is built not only on domestic obligations, but on obligations of 'international assistance and cooperation', describing these human rights obligations as essential to both national and 'global efforts'.98 Critically, wHo has highlighted that international assistance and cooperation is 'akin to ... domestic obligations, not subsidiary or secondary in any way', requiring that States give equal priority to rights everywhere - rather than prioritising the national to the exclusion of the global. ${ }^{99}$ Yet despite this early focus on extraterritorial human rights obligations in the CoviD-19 response, WHO entreaties for assistance and cooperation have come to be framed as a moral duty of solidarity rather than recognised as an international human rights obligation, denying accountability for global commitments.

Undermining human rights mainstreaming across global health governance, this fragmentation of human rights law and global health law is reflected in divergent COVID-19 responses between the UN's human rights institutions and other UN officials and bodies. Following the initial outbreak of CovID-19, the UN Secretary-General called for 'solidarity in new, creative, and deliberate ways for the common good and based on the core United Nations values that we uphold for humanity' ${ }^{\prime}{ }^{100}$ International organisations, including WHO, have continually reminded States that they bear moral responsibilities for international assistance and cooperation - but in a manner that is often untethered from international legal obligations to ensure the realisation of the right to health through global health governance. UN specialised agencies have long seen it as their responsibility to direct international cooperation within their respective areas of competence; ${ }^{101}$ however, human rights law has been largely absent from efforts to ensure international cooperation in the COVID-19 response. Seeking to catalyse global health leadership under human rights law in the pandemic response, the UN General Assembly has adopted repeated resolutions to call for international assistance and cooperation with

\footnotetext{
98 WHO, Addressing Human Rights as Key to the COVID-19 Response (2020).

99 Ibid.

100 UN, Shared Responsibility, Global Solidarity: Responding to the socio-economic impacts of COVID-19 (2O2O).

101 Sisule F. Musungu, 'Developing countries and the promotion of the right to health in multilateral institutions: A review of development in trade and health institutions', in Mary Robinson and Andrew Clapham (eds.), Realizing the right to health (Rüffer \& Rub 2009) 368.
} 
the full respect for human rights. ${ }^{102}$ Yet beyond these repeated calls to action, the implementation of global obligations to advance global health will require reforms in global governance.

\section{5}

\section{A Changing Landscape for Global Human Rights Obligations in Global Governance}

The covid-19 response highlights the critical need to reform global health governance to reshape global solidarity in global health and human rights. Although pathogens threaten the entire interconnected world, Covid-19 has exposed nationalist forces that have isolated States and exacerbated entrenched inequalities in power and resources, threatening the right to health worldwide. Amid repeated entreaties for global solidarity from wHO and the entire UN system, appealing for governments to see the global pandemic response as connected to their national self-interests, global governance has become disconnected from its human rights foundations, resulting in distributive failures, charitable approaches, and corporate profiteering. The struggle to advance global governance without global solidarity will continue to undermine efforts to address a wide range of global health challenges, with these health and human rights harms disproportionately threatening the Global South.

Such structural limitations in global governance reflect the neglect of global obligations, extraterritorial obligations of a global character, which require joint and separate action through international cooperation to realise human rights universally. ${ }^{103}$ These global obligations, 'the least elucidated and most unfulfilled' type of extraterritorial human rights obligations, ${ }^{104}$ can serve to underpin global governance with solidarity, empower marginalised individuals and groups, reduce health inequalities across nations, and promote global health with justice. Global obligations have long been central to Global South calls to transform global governance, with early advancement of a collective right to development explicitly looking to such extraterritorial obligations to advance global justice. ${ }^{105}$ As a basis to realise the right to health worldwide, global obligations can provide crucial frameworks in restructuring global

\footnotetext{
102 United Nations General Assembly, Resolution 74/306 Comprehensive and coordinated response to the coronavirus disease (COVID-19) pandemic (2020).

103 Extraterritorial Obligations Consortium, The Maastricht Principles on Extraterritorial Obligations of States in the Area of Economic, Social and Cultural Rights (2013).

104 Pribytkova (n 14) 339.

105 Balakrishnan Rajagopal, 'Right to Development and Global Governance: Old and New Challenges Twenty-Five Years On', (2013) 35 Human Rights Quarterly, 893.
} 
health governance, including responding to recent calls to decolonize global health, reform the UN system, and address systemic injustices such as global vaccine apartheid. ${ }^{106}$ Recognising the changing landscape for extraterritorial human rights obligations in global health, global obligations provide a foundation to support an augmented wHO role and a revitalised set of international organisations, with these governance reforms re-centring obligations for the universal realisation of the right to health in global health governance.

\subsection{Conceptualising Global Human Rights Obligations in Global Health Governance}

Global obligations extend extraterritorial obligations to institutions of global health governance. Reinforcing State obligations for acts and omissions that affect the enjoyment of rights beyond their territory, extraterritorial obligations also include 'obligations of a global character that are set out in the Charter of the United Nations and human rights instruments to take action, separately, and jointly through international cooperation, to realise human rights universally'.107 By embracing socio-economic rights deprivations that cannot be attributed to any particular actor, these global obligations have a "forward looking" character, considering "who can assist" rights-holders. ${ }^{108}$ These global obligations encompass global solidarity, capacity to assist, and reform of the international order.

The effective implementation of extraterritorial obligations in the covid19 response thus requires the implementation of global obligations through global health governance. In responding to this pandemic threat, the CESCR has sought to elaborate the extraterritorial obligations of States, including obligations to share research, medical equipment and supplies, and best practices in combating the virus; to realise equitable and universal access to vaccines; and to prevent intellectual property and patent regimes from making critical public goods such as vaccines or medicines inaccessible. ${ }^{109}$ The CESCR has looked to the collective global obligations of States both to assist other States

106 Sharifah Sekalala, Lisa Forman, Timothy Hodgson et al. 'Decolonising Human Rights: How Intellectual Property Laws Result in Unequal Access to the covid-19 Vaccine', (2021) BMJ Global Health 6:eoo6169.

107 Extraterritorial Obligations Consortium, Maastricht Principles on Extraterritorial Obligations of States in the Area of Economic, Social and Cultural Rights (2013).

108 Pribytkova (n 14) 425.

109 Committee on Economic, Social and Cultural Rights, Statement on the coronavirus disease (COviD-19) pandemic and economic, social and cultural rights (2020), UN Doc. E/C/12/202O/1; Committee on Economic Social and Cultural Rights, Statement on universal and equitable access to vaccines for the coronavirus disease (COvID-19) (2020), UN Doc. E/C.12/2020/2; Committee on Economic Social and Cultural Rights, Statement 
and to cooperate with $\mathrm{WHO}$, with this human rights guidance recognising that 'the role of the World Health Organization (wHO) in this field is fundamental and should be supported'.110 In doing so, the CESCR has reaffirmed an obligation of international cooperation in 'supporting international organisations, especially WHO, to respond to pandemics'.111

This CESCR guidance builds upon and clarifies human rights obligations under the ICESCR, which recognise the important role of international organisations as an institutional foundation to structure global obligations:

- Article 22 - the UN's specialised agencies should advise on 'international measures likely to contribute to the effective progressive implementation of the present Covenant'.

- Article 23 - 'international action for the achievement of the rights recognized in the present Covenant includes such methods as the conclusion of conventions, the adoption of recommendations, the furnishing of technical assistance ...'

It is clear from these ICESCR obligations that specialized agencies should take 'international action for the achievement of the rights recognized in the ... Covenant'.12 While global obligations are binding on States under the ICESCR, they also apply to other global actors, including international organisations and non-state actors. ${ }^{113}$ Drawing from international human rights law, international organisations can implement global obligations through global health governance under the auspices of WHO and the broader UN, with the covID19 response providing examples of, and shortcomings in, the implementation of global obligations across the global health governance landscape.

\subsection{Strengthening wHO Leadership to Realise Global Obligations}

wHO's mandate has always been to serve the interests of all nations across all health challenges, looking to human rights as a foundation for solidarity in global health, with the right to health providing a basis under the wHO Constitution to structure global obligations. However, States have long sought

on universal affordable vaccination against coronavirus disease (COVID-19), international cooperation and intellectual property (2O2O), UN Doc. E/C.12/2O21/1.

110 Committee on Economic, Social and Cultural Rights, Statement on the coronavirus disease (COviD-19) pandemic and economic, social and cultural rights (2020), UN Doc. $\mathrm{E} / \mathrm{C} .12 / 2020 / 1$.

111 Ibid.

112 Paul Hunt, 'Configuring the UN Human Rights System in the "Era of Implementation": Mainland and Archipelago', (2017) 39 Human Rights Quarterly, 489.

113 Extraterritorial Obligations Consortium, Maastricht Principles on Extraterritorial Obligations of States in the Area of Economic, Social and Cultural Rights (2013), principle 10; Pribytkova (n 14) 412. 
to constrain wHO's authorities, undermining WHO's authority and limiting financial support to serve their national interests. ${ }^{114} \mathrm{WHO}$ 's central role remains essential, but wHO lacks the autonomy to coordinate an effective global health response. With the resurgence of nationalism, even this limited authority has been challenged, as leaders have accused wHO of "favouring" other nations in the COVID-19 response and questioned WHO's public health guidance. ${ }^{115}$ Although wно has faced political obstacles in bringing nations together in the pandemic response, wHo has begun to look to the right to health as a renewed foundation of its leadership to rally the world. Where wHo was initially hesitant to condemn rights-violating policies, fearing political attacks from its own Member States, ${ }^{116}$ it has since emerged as a political leader in promoting rhetorical claims around the right to health in order to protect vulnerable populations, promote vaccine access, and plead for global solidarity.

The COVID-19 pandemic has provided wHO with the opportunity to seek an expanded and strengthened role under the right to health to facilitate global solidarity - seizing political leadership, negotiating international disputes, and providing technical and normative guidance in the pandemic response. WHO has long sought to strengthen its institutional authority to coordinate national health efforts, with the wно Director-General, just prior to the COVID-19 pandemic, calling for 'collaboration and partnership' through a strengthened WHO. ${ }^{117}$ Now looking to human rights as a foundation for global health governance in the equitable distribution of a COVID-19 vaccine, the wHO Director-General has argued that the right to health provides a basis to overcome vaccine nationalism and realise global solidarity: 'In a deadly pandemic, the right to health is the right to life. Every human has the right to be protected. But we need everyone protected as fast as possible - or else we all lose.'118 However, wH O's charitable paradigm for vaccine donations has proven unable to reach the magnitude of vaccines necessary to contain the disease in all countries, withhigh-incomeStates in the Global North negotiatingindependent deals with pharmaceutical companies to prioritise their own populations - leaving

\footnotetext{
114 Lawrence O. Gostin, Devi Sridhar, and Daniel Hougendobler, 'The normative authority of the World Health Organization', (2015) 129 Public Health, 854.

115 Benjamin Mason Meier, Allyn Taylor, Mark Eccleston-Turner, Roojin Habibi, Sharifah Sekalala, and Lawrence O. Gostin, 'The World Health Organization in Global Health Law', (2020) 48 The Journal of Law, Medicine \& Ethics.

116 Oona Hathaway and Alasdair Phillips-Robins, 'COVID-19 and International Law Series: Reforming the World Health Organization', (2020) Just Security.

117 Richard Horton, 'WHO powers up in 2019', (2019) 393 The Lancet, 14.

118 Tedros Adhanom Ghebreyesus, 'Vaccine Nationalism Harms Everyone and Protects No One', (2021) Foreign Policy.
} 
WHO's partnerships with insufficient donations to establish equitable access in all countries. ${ }^{119}$ While wHO has embraced international assistance and cooperation in its human rights guidance on COVID-19, ${ }^{120}$ extending this focus in its human rights advocacy on vaccine access, the organisation has not looked to extraterritorial obligations in framing its approach to human rights in global health. Drawing on human rights obligations as a basis for solidarity across nations, wHO can support all States to prepare for, rapidly detect, and respond to global health challenges.

For WHO to achieve global solidarity in global health, it will need to codify these global human rights obligations under global health law, aligning global health law with human rights law under the prospective pandemic treaty. ${ }^{121}$ Looking beyond IHR revisions to facilitate global solidarity, a new pandemic treaty can strengthen State obligations and wHo leadership, supporting global human rights obligations in global health law. ${ }^{122}$ These human rights obligations, made accountable through independent wHO review procedures, must be included in a pandemic treaty to limit nationalism, promote equality, and ensure solidarity in global health. ${ }^{123}$ The expected development of a pandemic treaty provides a unique opportunity to strengthen wHo leadership under global health law, structuring international cooperation as a global obligation across the global governance landscape.

\subsection{Mainstreaming Global Obligations across International Organisations}

As with WHO, it will be crucial to look across the entire UN as a foundation of global obligations to ensure global solidarity in global health. A wide range of UN institutions and affiliated organisations underlie public health in a globalising world, and all these institutions bear global obligations to implement

119 David McAdams, Kaci Kennedy McDade, Osondu Ogbuoji, Matthew Johnson, Siddharth Dixit, and Gavin Yamey, 'Incentivising wealthy nations to participate in the CovID-19 Vaccine Global Access Facility (COVAX): a game theory perspective', (2020) BMJ Global Health.

120 WHO, Addressing Human Rights as Key to the COvID-19 Response (2020).

121 Roojin Habibi, Tim Fish Hodgson, Benjamin Mason Meier, Ian Seiderman, and Steve Hoffman, 'Reshaping Global Health Law in the Wake of COVID-19 to Uphold Human Rights', (2021) OpinioJuris.

122 awrence O. Gostin, Benjamin Mason Meier, and Barbara Stocking, 'Developing an Innovative Pandemic Treaty to Advance Global Health Security', (2021) 49 The Journal of Law, Medicine \& Ethics, 5 ○3.

123 Sara Davis, 'An international pandemic treaty must centre on human rights', (2021) The BMJ Opinion. 
human rights in their organisational policies, programmes, and practices. ${ }^{124}$ However, the UN has faced obstacles in developing a coordinated approach to global solidarity through human rights in the pandemic response. In April 2020, the UN released initial guidance, 'COVID-19 and Human Rights: We Are All in This Together', to highlight the necessity of human rights in an effective covid-19 response. Yet, in proclaiming the need for global solidarity in the global health response, this UN guidance framed 'international assistance and cooperation', including through global governance institutions, as a moral responsibility rather than a legal obligation. ${ }^{25}$ While many UN agencies have provided human rights guidance in the pandemic response, ${ }^{126}$ few have engaged with extraterritorial obligations to support necessary cooperation to realise human rights in global health. ${ }^{127}$ Likewise, the three central strands of the UN's response - the UN's CovID response plan, humanitarian response plan and framework to mitigate social and economic impacts - are all grounded in human rights and emphasize global governance, solidarity, cooperation and assistance as central to the CoviD-19 response, but they fall short of recognising the human rights obligations underpinning solidarity and cooperation.

The UN has since come to actively embrace the development of new global governance institutions to facilitate international assistance and cooperation. These initiatives have arisen in the pandemic to encourage the equitable production and distribution of medical supplies, including CoviD-19 tests and vaccines, in an effort to pool resources in the global response and increase accessibility of treatment to every nation. ${ }^{128}$ Drawing from the Access to COVID-19 Tools (ACT) Accelerator, ${ }^{129}$ WHO joined the Coalition for Epidemic

124 Benjamin Mason Meier and Lawrence O. Gostin, 'Responding to the Public Health Harms of a Globalizing World through Human Rights in Global Governance' in Human Rights in Global Health: Rights-Based Governance for a Globalizing World (ouP 2018).

125 António Guterres and UN, Covid-19 and Human Rights: We Are All in This Together (2O2O).

126 UNAIDs, Rights in a Pandemic: Lockdowns, Rights, and Lessons from HIV in the Early Response to Covid-19 (2020); UNFPA, Coronavirus Disease (covid-19) Pandemic UNFPA Global Response Plan (2020); UnEsco International Bioethics Committee (IBC) \& Unesco World Commission on the Ethics of Scientific Knowledge and Technology, Statement on CoviD-19: Ethical Considerations from a Global Perspective (2020).

127 UNAIDS, Rights in the time of COVID-19 - Lessons from HIV for an effective, communityled response (2020).

128 UN, United Nations Comprehensive Response to Covid-19: Saving Lives, Protecting Societies, Recovering Better (2020).

129 Suerie Moon, Anna Bezruki, Gian Luca Burci, Temmy Sunyoto, Marcela Vieira, The Global Governance of Access to Countermeasures (Graduate Institute of International and Development Studies, Global Health Centre WP 20/2020). 
Preparedness Innovations (CEPI) and The Vaccine Alliance (Gavi) as coleaders in establishing covax. The covax initiative has acknowledged that lower-income States face structural and financial obstacles to obtaining access to COVID-19 vaccines for their peoples, seeking global solidarity to ensure equitable access to COVID-19 vaccine protection (with particular support for the most at-risk populations). However, this initiative to support global solidarity in COVID-19 vaccinations has faced limitations in its reliance on charitable donations rather than legal obligations. ${ }^{130}$

Implementing global obligations under international law will require greater collaboration across institutions of global health governance and human rights governance. The UN human rights system - comprising the treaty monitoring bodies, the Human Rights Council and its Special Procedures, and the Office of the High Commission for Human Rights (OHCHR) - is mandated to provide interpretive guidance on and oversight of human rights, with the Human Rights Council and OHCHR overseeing human rights mainstreaming across the UN. ${ }^{131}$ Throughout the COVID-19 response, these bodies have issued hundreds of statements, guidance notes, and reports interpreting international human rights law in the COVID-19 response, and in doing so, they have placed unprecedented emphasis on extraterritorial obligations. This focus on extraterritorial obligations has been extended by the UN Independent Expert on human rights and international solidarity, who has called on States to ensure vaccine access through efforts to 'withdraw their objections and support the application to the wTO Council for [TRIPS] for the explicit exemption of COVID-19 diagnostics, therapeutics and vaccines from certain provisions of the [intellectual property regime]' and pressed States to codify a declaration on the right to international solidarity. ${ }^{132}$

While providing interpretive clarity for implementing global obligations across institutions of global health governance, the UN human rights system will also be crucial in overseeing implementation of global obligations through overlapping accountability mechanisms. These human rights mechanisms have begun to provide scrutiny of State cooperation in global health governance, with the CESCR recommending that high-income States in the Global North leverage their membership in international and regional organisations

\footnotetext{
130 Armin von Bogdandy and Pedro Villarreal, 'The Role of International Law in Vaccinating Against COVID-19: Appraising the COVAX Initiative', (2021) 81 Heidelberg Journal of International Law, 89 .

131 Paul Hunt (n 117) 489.

132 Obiora Chinedu Okafor, International solidarity in aid of the realization of human rights during and after the coronavirus disease (COVID-19) pandemic (2021) A/HRC/47/31, para. $48(\mathrm{~d})$.
} 
to advocate for universal access to COVID-19 vaccines and medicines. ${ }^{133}$ While the Human Rights Council's Universal Periodic Review has thus far provided limited oversight and recommendations on Covid-19 responses, it has the potential to issue constructive global governance recommendations to states under review. ${ }^{134}$ The cooperative engagement of institutions of global health governance will be crucial to supporting these UN human rights review procedures, providing technical expertise as human rights mechanisms seek to interpret global obligations in the context of global health governance and recommend actions of international organisations and Member States in meeting their global obligations. ${ }^{135}$

\subsection{Reshaping Governance Structures to Recentre Equity and Human Rights in Global Health}

Beyond these institutional reforms, it will be necessary to fundamentally reshape global governance to recentre human rights in global health, mainstreaming global obligations to realise the right to health on an equitable basis throughout the world. Superficial attention to human rights in global health governance - declaring health a human right in political statements without accompanying policies, programmes, or practices - has rendered international institutions ill-equipped to realise global obligations, unable to meet the post-war promise of global solidarity. Without meaningful commitments to human rights, the broader global governance ecosystem has been accused of entrenching global inequities and perpetuating neo-colonial power relations, threatening the right to health in the Global South. This has led activists and scholars to question whether human rights commitments are part of the solution or part of the problem, ${ }^{136}$ considering whether human rights law has remained true to its transformative potential or been co-opted for anti-transformational ends. ${ }^{137}$ To realise the right to health through global obligations, it will be essential not only to mainstream extraterritorial human

133 See, e.g., Committee on Economic, Social and Cultural Rights, Concluding observations on the seventh periodic report of Finland (2O21), UN Doc. E/C.12/FIN/CO/7, para. 9 .

134 Miloon Kothari, 'The UN's Universal Periodic Review must respond to COVID-19', (2021) OpenGlobalRights.

135 Judith Bueno de Mesquita, Rebekah Thomas, Camille Gautier, et al., 'Monitoring the sustainable development goals through human rights accountability reviews', (2018) 96 Bulletin of the World Health Organization, 627.

136 Samuel Moyn, Not Enough: Human Rights in an Unequal World (HUP 2018).

137 Malcolm Langford, Fons Coomans, and Felipe Gómez Isa, 'Extraterritorial Duties in International Law', in Malcolm Langford (eds.), Global Justice, State Duties: The Extraterritorial Scope of Economic, Social, and Cultural Rights in International Law (CUP 2013). 
rights obligations through global health governance but to address underlying structural limitations within international law, including dominant neoliberal ideologies, racist colonial mindsets, and imbalanced power relations that limit the influence of international human rights law in shaping global health.

With this broader governance system implicated as a structural impediment to global human rights obligations, international human rights law has seen limited success in addressing the harms arising in global governance. ${ }^{138}$ International human rights law has offered much promise to the Global South to reform the international order, but parallel systems of international law have constrained these demands through international trade, investment, and economic law, underpinned by Global North conceptions of economic growth and development. ${ }^{139}$ These tensions play out in the fragmentation of international law, the political arenas within which it operates, and the neoliberal and neocolonial development models that underpin it. Seen in the tensions between the protection of public health under international human rights law and the protection of economic interests under international intellectual property law, vaccine production has been restricted by patent protections, with vaccines developed and produced primarily in the Global North and - as seen in the production of HIV anti-retroviral therapies two decades earlier - rising vaccine "apartheid" between the Global North and South. Prioritising access to vaccines as a human right, and recognising that 'production and distribution of vaccines must be organized and supported by international cooperation and assistance', international human rights mechanisms have endorsed the use of flexibilities under the TRIPS Agreement to limit patent protections to promote equitable global access to vaccines. ${ }^{140}$ However, in a UN Human Rights Council resolution on 'Ensuring equitable, affordable, timely and universal access for all countries to vaccines in response to the coronavirus disease (COVID-19) pandemic', whilst States recognised flexibilities under the TRIPS agreement, they declined to frame this TRIPS "waiver" as a human rights obligation. Further reflecting the dominance of patent law over human rights law, a coalition of high-income States has continued to block this waiver in the WTO, prioritising

138 John Linarelli, Margot Salomon, and Muthucumaraswamy Sornarajah, The Misery of International Law: Confrontations with Injustice in the Global Economy (2018).

139 Sundhya Pahuja, Decolonising International Law: Development, Economic Growth and the Politics of Universality (CUP 2011).

140 World Trade Organization, Waiver from certain provisions of the TRIPS agreement for the prevention, containment and treatment of CoviD-19 (2020), wTo Doc. IP/C/W/669. 
profit of the pharmaceutical industry in the Global North over saving the lives of the most vulnerable populations in the Global South. ${ }^{141}$

Overcoming this fragmented system, it will be necessary to harmonise global human rights obligations at the centre of international law, providing a path to international assistance and cooperation in global health governance. Realising these global obligations requires a reorganisation of the current legal regime in which health has been treated as a commodity and driver of profit rather than a human right. The realisation of global obligations through global governance will require institutional structures to be reshaped to reflect the founding ideals of the UN - solidarity, equality, and human rights.

\section{Conclusion: Strengthening Human Rights in Global Health Governance}

The world is facing an unprecedented global health threat, and the response is exposing longstanding structural obstacles in global health governance, limiting the implementation of human rights obligations to ensure international cooperation. The founding principles of global solidarity that underpin international human rights law and global health law hold much promise but have been missing in many States' commitment to global health governance in the CoviD-19 response. Rising tides of nationalism and isolationism have undermined global health governance, exacerbating health and human rights inequities between the Global North and South. Global health governance is at a crossroads, necessitating the development of new governance models that take into account global obligations for human rights realisation. The world faces a clear choice: either to continue down an inequitable nationalist path or to work cooperatively through global obligations to realise shared governance in global health. Failure to strengthen human rights in global governance at this critical juncture could lead to permanent nationalist retrenchment and weakening of international organisations, dimming hopes for the future of human rights in global health.

Human rights obligations have potential to transform global health governance - in the pandemic response and beyond. So long as States can argue that international assistance is charity and international cooperation is voluntary, global solidarity will remain an elusive goal - one more regret upon the altar of

141 Tim Fish Hodgson and Rossella de Falco, 'Human Rights and Universal Access to COVID19 Vaccines: Does the Human Rights Council Resolution go far enough?' Opinio Juris (23 March 2021). 
failed political commitments. Yet, changes in global governance provide new opportunities to realise human rights, with the development of new legal obligations providing hope for global solidarity under global health law. Realising the rights-based promise of global obligations for global health will require sustainable, well-resourced global governance institutions for facilitating coordination and cooperation across the international community, pursuing health as a human right rather than a commodity, and committed to eliminating global health inequities. The global governance institutions that develop amid this COVID-19 crisis will determine the response to future threats. It will be crucial that these reforms of global health governance sustain the mainstreaming of human rights through global obligations. 